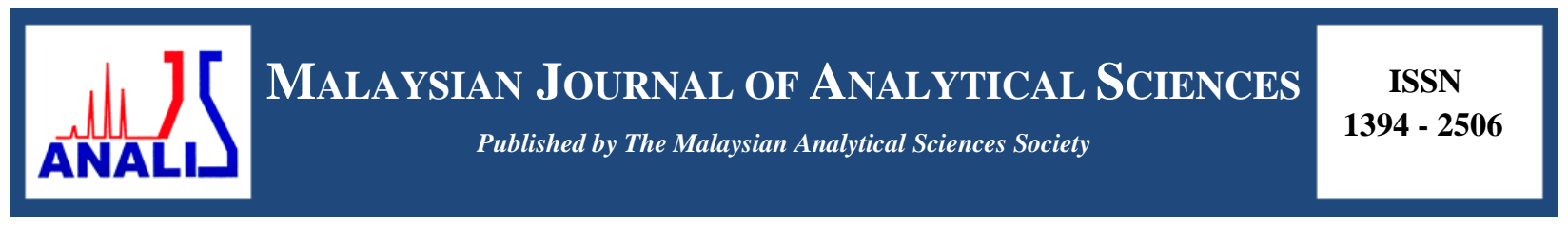

\title{
ADSORBENT FROM WASTE AND NATURAL DEPOSITS FOR PARAQUAT REMOVAL IN WATER
}

\section{(Penjerap daripada Sisa Industri dan Semulajadi untuk Penyingkiran Paraquat di dalam Air)}

\author{
Nur Fatin Zakaria ${ }^{1}$, Zaiton Abdul Majid ${ }^{1}$, Zainab Ramli ${ }^{1}$, Jafariah Jaafar ${ }^{1}$, Azmi Aris ${ }^{2,3}$, Juhaizah Talib ${ }^{2,3}$, \\ Rusmidah $\mathrm{Ali}^{1}$ \\ ${ }^{I}$ Department of Chemistry, Faculty of Science \\ ${ }^{2}$ Department of Environmental Engineering, Faculty of Civil Engineering \\ ${ }^{3}$ Institute of Environmental and Water Resource Management, \\ Universiti Teknologi Malaysia, 81310 Johor Bharu, Johor, Malaysia \\ *Corresponding author: zaiton@kimia.fs.utm.my
}

Received: 9 December 2014; Accepted: 21 March 2016

\begin{abstract}
Studies on the removal of frequently used herbicide for controlling broad-leafed weeds, Paraquat Dichloride (PQ) has been carried out intensively. Waste from steelmaking industries (Electric Arc Furnace (EAF) slag) and natural zeolite (clinoptilolite) were used as the starting materials. Preparation of an adsorbent involved two steps, namely extraction iron oxide (IO) from slag and precipitation of IO onto clinoptilolite. Characterization of NZIC were done using Fourier Transform Infrared spectroscopy (FTIR), Scanning Electron Microscopy (SEM), single-point Brunauer Emmett Teller (BET) surface area analysis, Vibrating Sample Magnetometer (VSM) and $\mathrm{pH}$ at zero point charge (pHzpc). The NZIC showed a lower magnetic saturation at 8.13 $\mathrm{emu} / \mathrm{g}$ compared to maghemite at $29.5 \mathrm{emu} / \mathrm{g}$. The BET surface area of NZIC was $146.29 \mathrm{~m}^{2} / \mathrm{g}$, larger compared to the individual surface area of clinoptilolite and maghemite which are 37.84 and $17.84 \mathrm{~m}^{2} / \mathrm{g}$ respectively. Adsorption of PQ onto clinoptilolite and NZIC were investigated using a batch experiment. Surface characteristic of NZIC was investigated by pHzpc experiment showing that at $\mathrm{pH} 8.2$ its electric surface charge is zero. Optimum parameters for adsorption of PQ in water were found at $\mathrm{pH}$ 12 with $0.01 \mathrm{~g} / 10 \mathrm{~mL}$ of NZIC and equilibrium time of 20 minutes. Desorption experiment revealed that NZIC have a good recovery in repetitive usage for $\mathrm{PQ}$ removal in water.
\end{abstract}

Keywords: waste, clinoptilolite, iron oxide, paraquat, adsorption

\section{Abstrak}

Kajian ke atas penghapusan racun rumpai yang sering digunakan untuk mengawal tumbuhan berdaun besar, Paraquat Diklorit (PQ) telah dijalankan secara intensif. Sisa daripada industri keluli dan zeolit asli (klinoptilolit) telah digunakan sebagai bahan mentah. Elektrik relau arka (EAF) sanga mengandungi logam oksida berharga seperti oksida besi (IO) yang merangkumi 37\% (w/w) sanga. Kajian ini memberi tumpuan untuk mengekstrak IO dan pemendakan ke atas klinoptilolit. Penyediaan Zeolit-Besi Oksida Komposit (NZIC) melibatkan dua langkah mudah iaitu pengekstrakan IO dari sanga EAF dan pemendakan IO ke atas klinoptilolit. Pencirian NZIC telah dilakukan dengan menggunakan Fourier Transform Inframerah Spektroskopi (FTIR), Imbasan Elektron Mikroskopi (SEM), analisis kawasan permukaan Brunauer Emmett Teller (BET), Vibrating Sample Magnetometer (VSM) dan pH di caj titik sifar (pHzpc). NZIC menunjukkan ketepuan magnet yang rendah iaitu pada 8.13 emu/g berbanding maghemite dengan ketepuan magnet 29.5 emu/g. Kawasan permukaan BET untuk NZIC adalah $146.29 \mathrm{~m}^{2} / \mathrm{g}, \mathrm{lebih}_{\mathrm{besar}}$ berbanding dengan kawasan permukaan individu klinoptilolit dan maghemite, 37.84 dan $17.84 \mathrm{~m}^{2} / \mathrm{g}$ masing-masing. Penjerapan PQ ke atas klipnotilolit dan NZIC telah disiasat menggunakan eksperimen kumpulan. pHzpc untuk NZIC adalah pada pH 8.2 di mana caj permukaannya adalah seimbang. Parameter optimum untuk penjerapan PQ dalam air didapati pada pH 12 dengan 0.01 g/10 mL NZIC dan keseimbangan masa iaitu 20 minit. Eksperimen penyaherapan menunjukkan NZIC mempunyai kadar pemulihan yang baik dalam penggunaan berulang-dalam penyingkiran PQ di dalam air. 
Kata kunci: sisa, klinoptilolit, ferum oksida, paraquat, penjerapan

\section{Introduction}

Paraquat (1,1'-dimethyl-4,4'-bipyridinium) is a highly effective herbicide used to control weeds and grass in agricultural area. Commonly, farmers tend to spray the diluted herbicides to the plant area and eventually the excess PQ may reach the source of fresh water by leaching from soil. Paraquat (PQ) is hydrophilic compound and it is highly soluble in water. Paraquat is classified as toxic to human and environment. The maximum concentration level (MCL) of PQ in drinking water is $20 \mu \mathrm{g} / \mathrm{L}$ according to United States Environmental Protection Agency (USEPA). Hence, efficient method for pesticides removal in water is constantly being researched. Various techniques has been research including adsorption $[1,2]$ and advanced oxidation process (AOP) via catalyst and Fenton [3-5]. Adsorption is considered a feasible method for pesticides removal due to its simplicity, costeffectiveness and high removal.

The use of agricultural and industrial waste as precursors in the preparation of adsorbent constantly studied. In this study, electric arc furnace (EAF) slag and clinoptilolite were used as the starting materials for the production of an adsorbent. Natural zeolite namely clinoptilolite is a cation exchanger and have high selectivity properties. The selectivity and size exclusion of zeolite offers more effective removal of PQ. The performance of synthetic and natural zeolite in removing contaminants is not much different [6]. Zeolites also reduce the effect of NOM in adsorption of contaminant in real water sample [7].

The EAF slag is a highly available material from steel-making industry wastes and comprised of many valuable metal oxides such as Zinc (Zn), Iron (Fe), Calcium (Ca), Copper (Cu) and Manganese ( $\mathrm{Mn})$ [8]. Numerous works have been reported on the recovery of these valuable materials from slag. For example, Saufi [8] extracted Fe to use to enhance its carbon nanotube (CNT). On the other hand, Shawabkeh [9], Fallman [10] and Orhan [11] studied on maximizing Zinc, Chromium and Barium recovery from slag. In this work, iron was extracted from EAF slag and precipitated onto clinoptilolite to produce an adsorbent for the removal of PQ in water.

\section{Raw material}

\section{Materials and Methods}

Electric arc furnace slag was collected from Antara Steel Mills (M) Sdn.Bhd and clinoptilolite was purchased from Shafzan Feed and Fertilizer. Both raw materials were ground and sieved to a particle size of $75 \mu \mathrm{m}$ prior to use. Clinoptilolite was first activated by agitating in $2 \mathrm{M}$ sodium chloride $(\mathrm{NaCl})$ solution [12]. Paraquat standard was purchased from Fluka Analytical and used without further purification. Stock solution of PQ was prepared by dissolving standard paraquat in double distilled water. The working solution of PQ was prepared by series of dilution from the stock solution prepared.

\section{Preparation of Natural Zeolite-Iron Oxide Composite (NZIC)}

The NZIC was prepared via two simple steps. First, iron oxide (IO) was extracted from EAF slag, followed by the precipitation of iron (hydr)oxide onto clinoptilolite. Powdered EAF slag was added to ammonium chloride $\left(\mathrm{NH}_{4} \mathrm{Cl}\right)$ solution and the mixtures were refluxed for 2 hours. A desired amount of clinoptilolite was added to the filtrate solution to make a 3 to 1 amount of clinoptilolite to iron oxide. Concentrated sodium hydroxide $(\mathrm{NaOH})$ was added dropwise to the filtrate with an aid of sonication. The mixture was stirred for another 2 hours until homogenous suspension was obtained. Synthesized product was filtered, washed and dried overnight in an oven at $70^{\circ} \mathrm{C}$. Final product was calcined in a box furnace at $500^{\circ} \mathrm{C}$ for two hours at a temperature rate of $10{ }^{\circ} \mathrm{C} / \mathrm{min}$.

\section{Characterization of NZIC}

Fourier Transform Infra-red (FTIR) spectroscopy (Perkin Elmer, Spectrum One) was used to analyse the functional groups found in the clinoptilolite and NZIC prepared at a spectral range of $4000 \mathrm{~cm}^{-1}$ to $400 \mathrm{~cm}^{-1}$. The morphology of clinoptilolite, maghemite and NZIC were observed using Scanning Electron Microscopy (SEM) (Phenom G2 Pro). Effect of surface area of clinoptilolite, maghemite and NZIC were studied using single-point Brunauer Emmett Teller (BET) surface area analysis. Magnetic properties of maghemite and NZIC were analysed using Vibrating 
Sample Magnetometer (VSM) at room temperature. Zero point charge (zpc) of NZIC was determined by pH at zero point charge (zpc) experiment [13].

\section{Removal of Paraquat in water by NZIC}

Adsorption experiment for study on effect of time, adsorbent dosage and $\mathrm{pH}$ in paraquat removal by NZIC were conducted in a batch mode study. The experiment take place in thermostat orbital shaker (Lab Companion) and experiments were repeated to ensure the reproducibility of the result is obtained. Adsorption and desorption experiment were done using $10 \mathrm{mg} / \mathrm{L}$ PQ standard solution followed by desorption with distilled water. Initial and final concentration of PQ was quantified using calibration curve of PQ standard, analysed by UV-Vis spectrophotometry (UV-Vis-Perkin Elmer Lambda25 Spectrophotometer) at maximum absorption wavelength of $257 \mathrm{~nm}$.

\section{Characterization of NZIC}

\section{Results and Discussion}

\section{Fourier Transform Infra-red}

Spectra of clinoptilolite, maghemite and NZIC in Figure 1 showed an intense peak at $1028 \mathrm{~cm}^{-1}$ indicates the presence of internal vibration of tetrahedral Si-O and Al-O. At $450 \mathrm{~cm}^{-1}$ band showed the vibration of O-Al-O or OSi-O bonds. The existence of in-plane-bending vibration of water $\left(\mathrm{H}_{2} \mathrm{O}\right)$ and $\mathrm{OH}$ bending in clinoptilolite and maghemite observed at $1637 \mathrm{~cm}^{-1}$ and $3447 \mathrm{~cm}^{-1}$ respectively were due to moisture in the sample preparation. Low band at wavenumber of 600 and $790 \mathrm{~cm}^{-1}$ found at spectrum of maghemite and NZIC were attributed to the characteristics band of iron oxide [14].

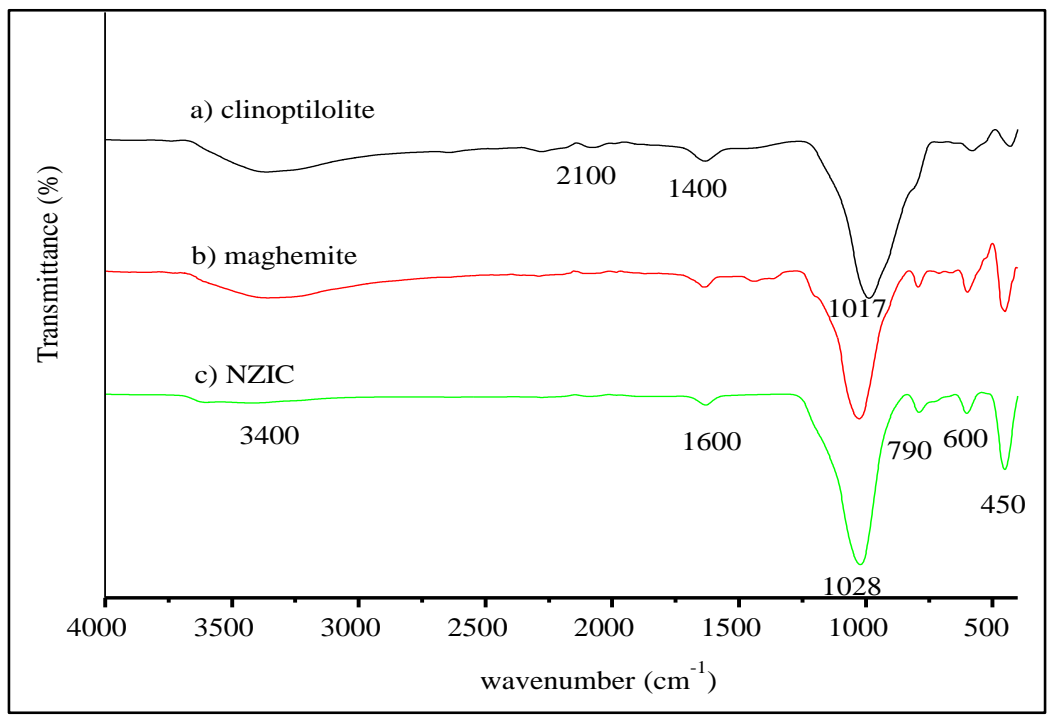

Figure 1. IR spectra of a) clinoptilolite, b) maghemite, and c) NZIC

\section{Scanning Electron Microscopy micrograph}

SEM images of clinoptilolite, maghemite and NZIC were shown in Figure 2. Micrograph in Figure 2a showed an irregularly shaped of clinoptilolite. Maghemite poses a prismatic and flake-like shape as observed in Figure $2 b$. Maghemite was scattered around clinoptilolite in Figure 2c showing the effective effect of dispersive by sonication in preparation of NZIC procedure. 

WATER

\section{Magnetic saturation}

Figure 3a showed the hyteresis loop for maghemite and NZIC analysed by VSM at room temperature indicate curve for paramagnetism materials. Magnetic saturation of maghemite and NZIC were 29.55 and $8.13 \mathrm{emu} / \mathrm{g}$ respectively. Magnetic curve of maghemite and NZIC showed small loop indicating the remaining of magnetic reflux in the sample eventhough magnetic force is zero. Figure $3 \mathrm{~b}$ suggested that NZIC in water was attracted effectively when external magnetic field was introduced. The decreasing effect of magnetic saturation in NZIC sample was due to small amount of maghemite in per gram of NZIC as well as the presence of non-magnetic material, clinoptilolite in NZIC..
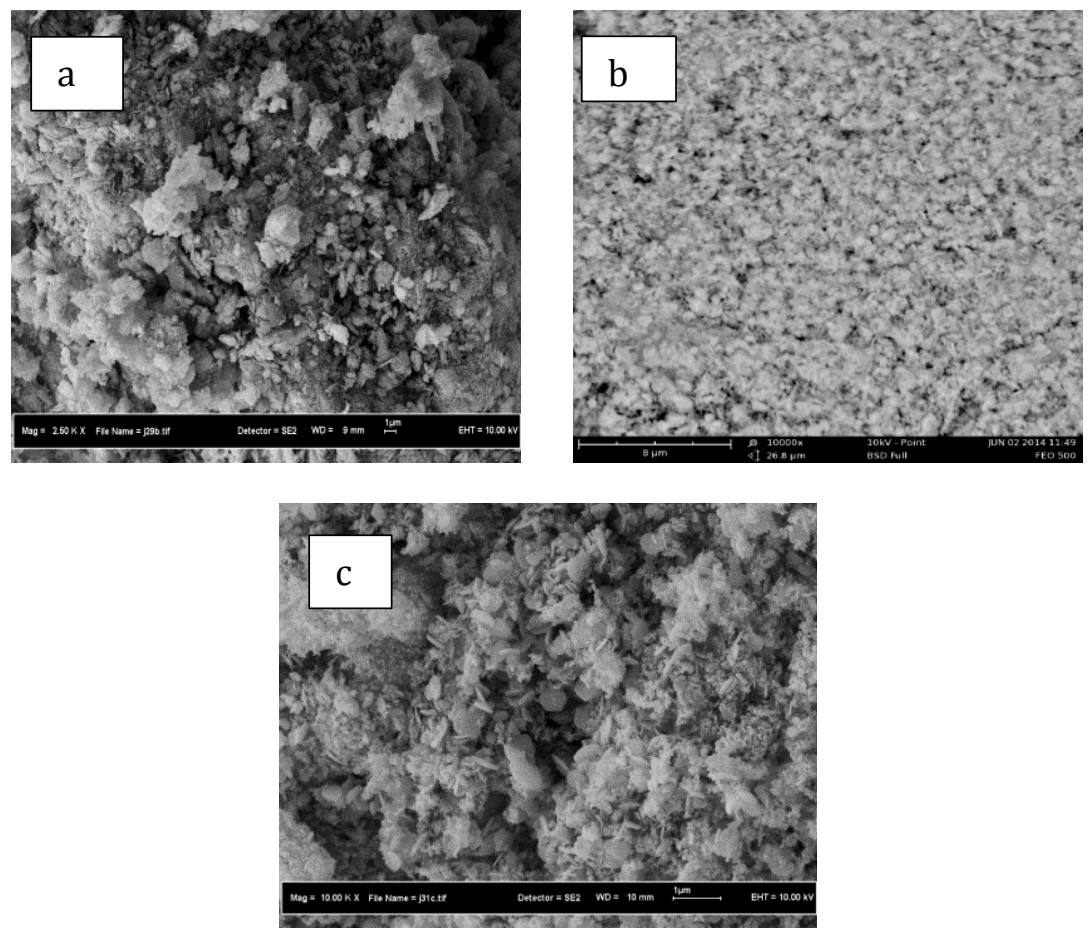

Figure 2. Micrograph of a) clinoptilolite, b) maghemite, and c) NZIC

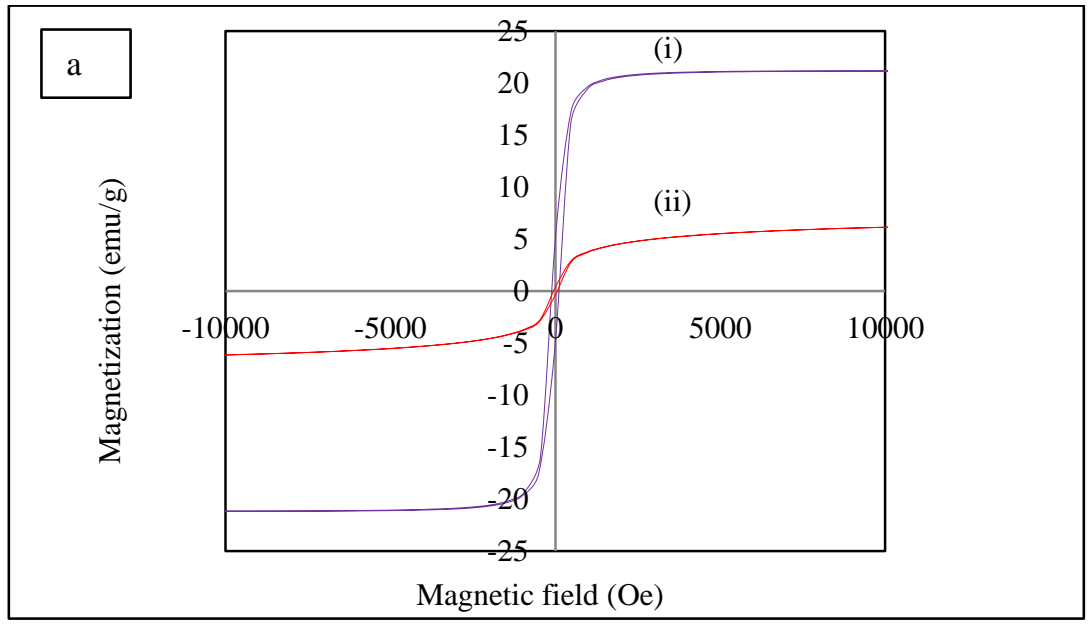




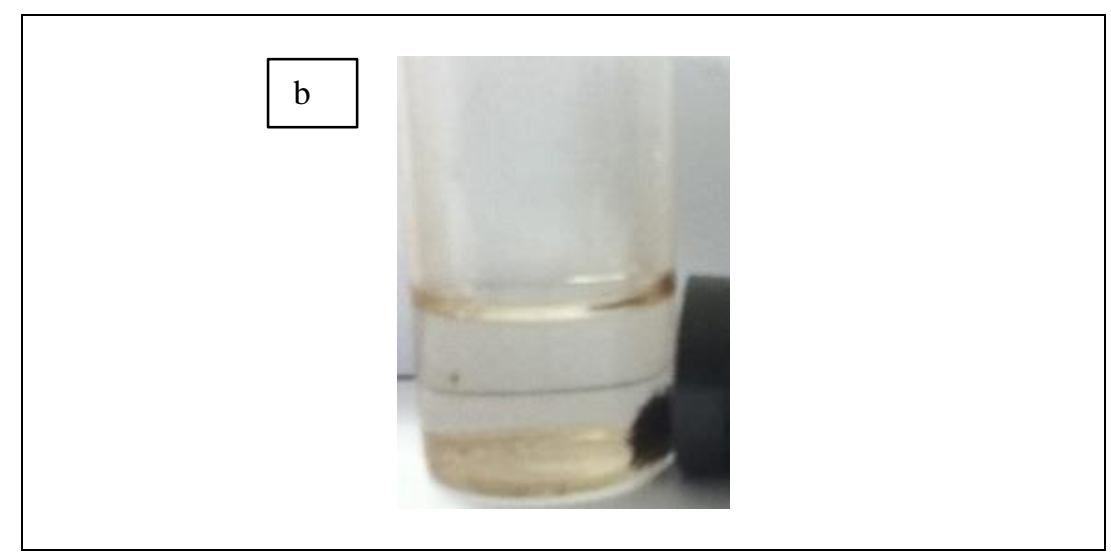

Figure 3. a) Magnetization curve of i) maghemite and ii) NZIC at $300 \mathrm{~K}$, and b) magnetic attraction of NZIC towards external magnetic application

\section{Surface area}

The surface areas of raw materials, clinoptilolite and EAF slag as well as maghemite and NZIC were presented in Table 1. Iron oxide showed a small surface area due to the agglomeration effects and its mutual magnetic attraction. By modification of maghemite with clinoptilolite, the surface area increase almost four fold. The larger surface area of an adsorbent, then the bigger active site available for adsorption to take place.

Table 1. Surface area of clinoptilolite, EAFS, iron oxide and NZIC

\begin{tabular}{lllll}
\hline Sample & Clinoptilolite & Raw EAFS & Maghemite & NZIC \\
\hline Surface $a r e a, \mathrm{~m}^{2} / \mathrm{g}$ & 37.84 & 3.02 & 9.62 & 146.29 \\
\hline
\end{tabular}

\section{pH at zero point charge}

The $\mathrm{pH}$ at zero point charge $\left(\mathrm{pH}_{\mathrm{zpc}}\right)$ for NZIC was determined by mixing $0.15 \mathrm{~g}$ NZIC in $0.01 \mathrm{M}$ concentration of $\mathrm{NaCl}$ and varying the $\mathrm{pH}$ of the solution from $\mathrm{pH} 2-13$. After 24 hours agitation, the resulting mixtures were analysed for its $\mathrm{pH}$. The plot of initial and final $\mathrm{pH}$ in Figure 4 showed an intersection of the two curves at $\mathrm{pH}$ 8.2. At this point, the NZIC surface charge is considered neutral. The adsorption of PQ depends on the $\mathrm{pH}$ of solution as $\mathrm{PQ}$ exists in its cationic form in water. At lower $\mathrm{pH}$, surface of NZIC was saturated with hydronium ions $\left(\mathrm{H}_{3} \mathrm{O}^{+}\right)$, thus high competition of these positively charge paraquat $\left(\mathrm{PQ}^{+}\right)$and $\mathrm{H}_{3} \mathrm{O}^{+}$decreased the adsorption of $\mathrm{PQ}$.

\section{Paraquat removal by NZIC}

Figure 5 shows the plots of PQ removal by clinoptilolite, maghemite and NZIC against time. Adsorption of PQ by clinoptilolite and NZIC (3:1) were rapid at first and reached plateau after 20 minutes contact time. The equilibrium time of PQ removal was attained at the 20th minutes. From the graph in Figure 5, maghemite showed a very low adsorption, means that maghemite was not a good adsorbent. Although the surface area of NZIC was higher than clinoptilolite, but, the removal of paraquat by clinoptilolite was slightly higher than NZIC. As observed in Figure 5, low removal of PQ is observed despite a high surface area of NZIC. This is due to the existence of maghemite in NZIC. 


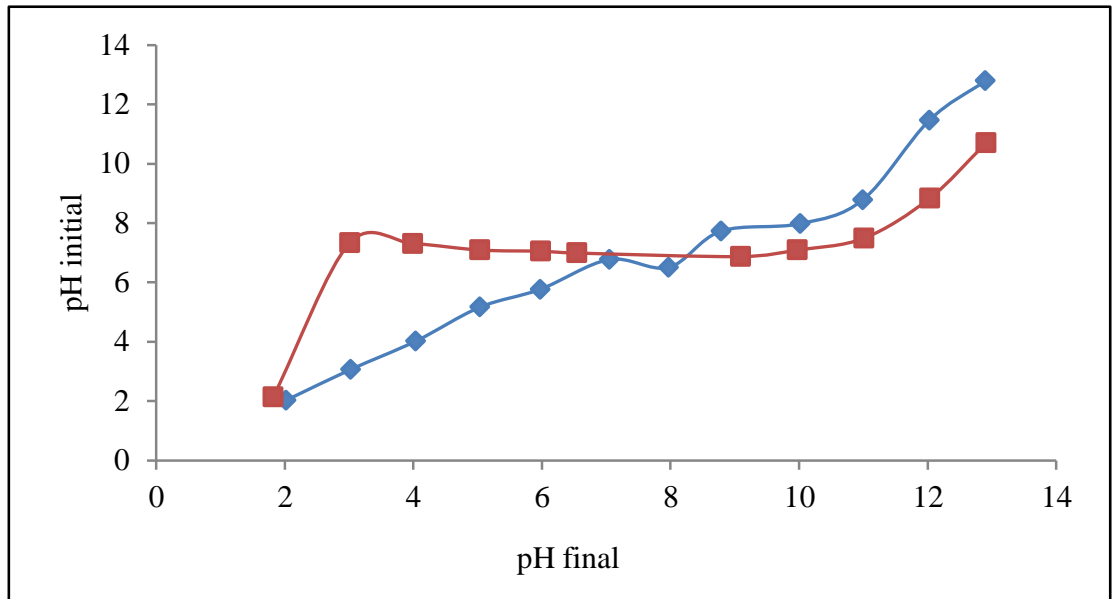

Figure 4. The pH at zero point charge of NZIC

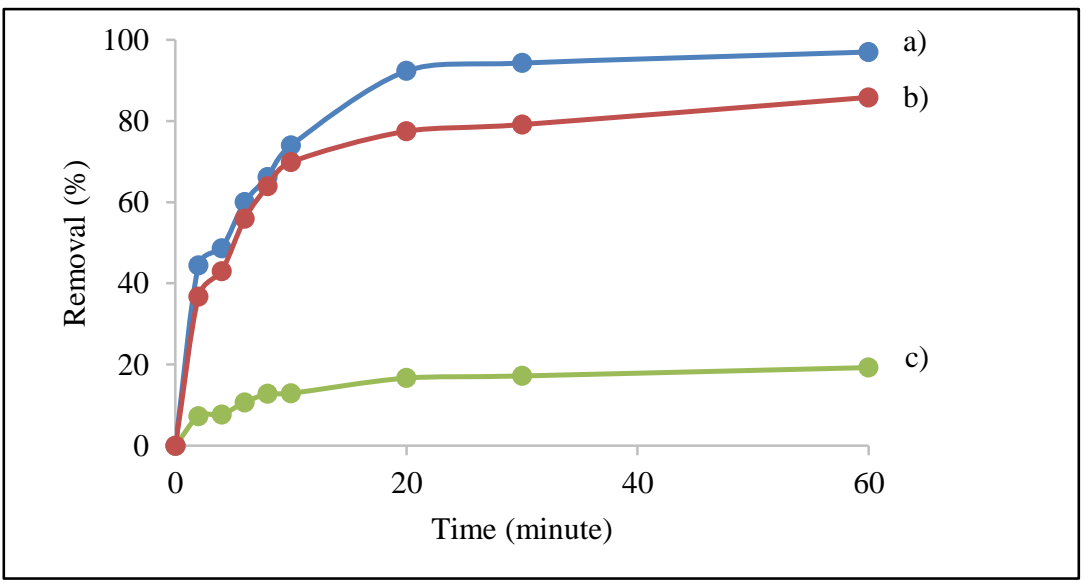

Figure 5. Comparison on the PQ removal by a) clinoptilolite, $\mathrm{b}$ ) maghemite and $\mathrm{c}$ ) NZIC (initial PQ concentration = $10 \mathrm{mg} / \mathrm{L}$, Adsorbent dosage $=0.01 \mathrm{~g}, \mathrm{pH}=$ neutral)

Plot in Figure 6 indicates that paraquat uptake increased with increasing pH. Maximum PQ uptake was obtained at $\mathrm{pH}$ 12. The removal of $\mathrm{PQ}$ is highly dependent on initial solution $\mathrm{pH}$. This condition interrelated with the nature of $\mathrm{PQ}$ in water. The $\mathrm{pK}_{\mathrm{a}}$ value of cationic $\mathrm{PQ}$ is $9-9.5$ [14]. At higher $\mathrm{pH}$ than $\mathrm{pH}_{\mathrm{zpc}}$, higher concentration of hydroxide ions $\left(\mathrm{OH}^{-}\right)$was present on NZIC surface. Hence, NZIC acquired a negatively surface charge at higher $\mathrm{pH}$ and cationic PQ easily attached to the surface of NZIC via attraction force.

Figure 7 shows that NZIC have a good recovery of PQ in desorption experiment. At first adsorption-desorption experiment, $99 \%$ of PQ was adsorbed and desorbed into the solution. The performance of PQ removal after second and third time repetitive usage was decreased to $86 \%$. This small decreasing in percentage removal of PQ showed that the stability of these adsorbent for repetitive usage. 


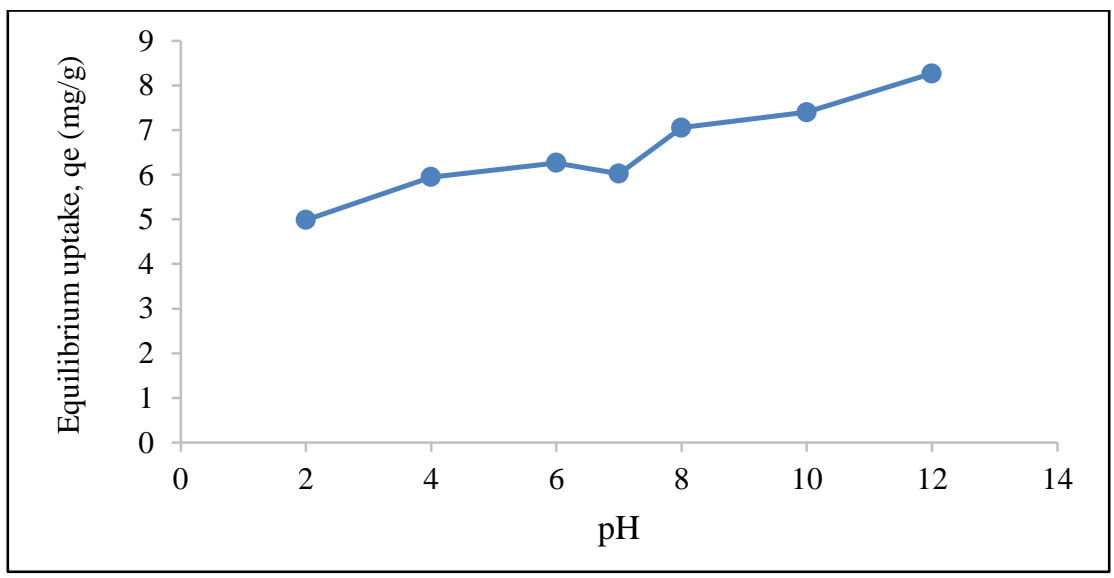

Figure 6. Effect of $\mathrm{pH}$ on PQ uptake by NZIC (initial PQ concentration $=10 \mathrm{mg} / \mathrm{L}$, Adsorbent dosage $=0.01 \mathrm{~g}$, $\mathrm{pH}=12)$

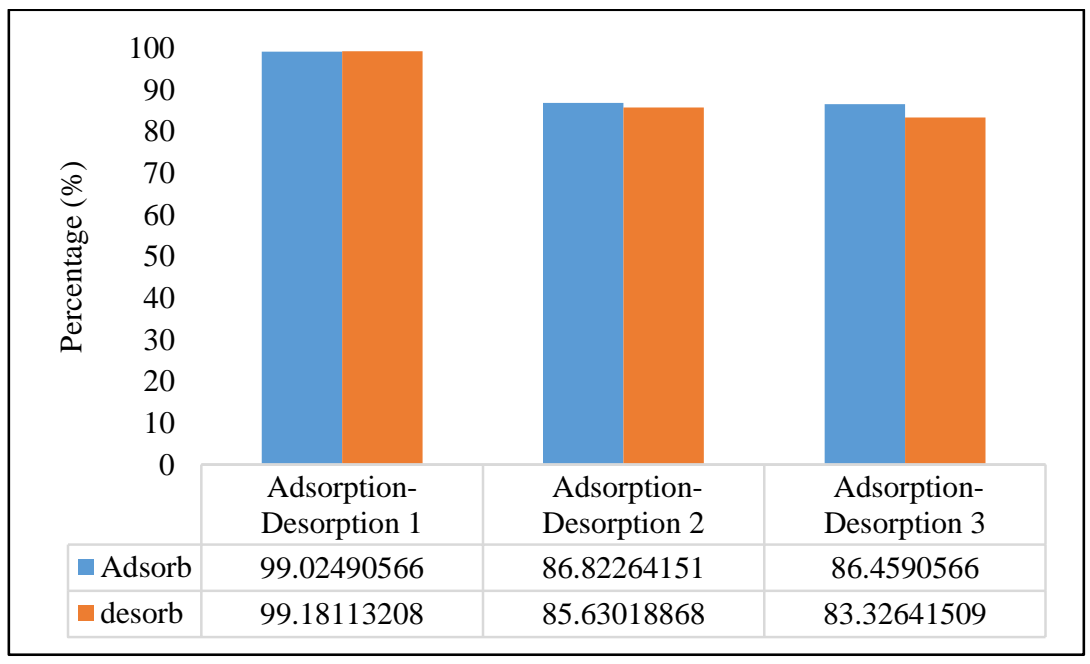

Figure 7. Repetitive adsorption of PQ onto NZIC (initial PQ concentration $=10 \mathrm{mg} / \mathrm{L}$, Adsorbent dosage $=0.01 \mathrm{~g}$, $\mathrm{pH}=12)$

\section{Conclusion}

Preparation of NZIC was done by extraction of iron oxide (IO) from slag and precipitation of IO onto clinoptilolite. Magnetization analysis of NZIC revealed the ability of maghemite in NZIC as a magnetic separator when external magnetic field was applied. Preliminary study showed that clinoptilolite have higher removal percentage of paraquat (96\%) compared to NZIC (86\%) due to nature of maghemite which is not a good adsorbent. Optimum parameters for adsorption of $10 \mathrm{mg} / \mathrm{L} \mathrm{PQ}$ in water were found at $\mathrm{pH} 12$ with $0.01 \mathrm{~g}$ of NZIC with equilibrium time of 20 minutes. Desorption experiment demonstrate that NZIC as a stable adsorbent for repetitive usage for PQ adsorption.

\section{Acknowledgement}

We would like to express our gratitude to Universiti Teknologi Malaysia, Institute of Environmental and Water Resource Management (IPASA) and Ministry of Higher Education (MOHE) for the financial support given under Long Term Research Grant, 4L810 and 4L812 and Fundamental Research Grant, 4F234. 


\section{References}

1. Rahman, I. A., Sing, Y.Y., Bari, M. F. and Saad, B. (2015). Adsorption of paraquat by treated and untreated rice husks studied by flow injection-analysis. Research Journal of Chemistry and Environment 9 (1): 13 - 18.

2. Hsu, S.-T. and Pan, T.-C. (2007). Adsorption of paraquat using methacrylic acid-modified rice husk. Bioresource Technology, 98 (18): 3617 - 3621.

3. Ali, R. and Hassan, S. H. (2008). Degradation studies on paraquat and malathion using $\mathrm{TiO}_{2} / \mathrm{ZnO}$ based photocatalyst. Malaysian Journal of Analytical Sciences, 12 (1): 77 - 87.

4. Santos, M. S. F., Alves, A. and Madeira, L. M. (2011). Paraquat removal from water by oxidation with Fenton's reagent. Chemical Engineering Journal, 175: 279 - 290.

5. Oliveira, C., Gruskevica, K., Juhna, T. and Tihomirova, K. (2014). Removal of paraquat pesticide with Fenton reaction in a pilot scale water system. Drinking Water Engineering Science, 7: 11 - 21.

6. Nah, I. W., Hwang, K.-Y., Jeon, C. and Choi, H. B. (2006). Removal of Pb ion from water by magnetically modified zeolite. Mineral Engineering, 19 (14): 1452 - 1455.

7. Ridder D. J. (2012). Adsorption of organic micropollutants onto activated carbon and zeolites. Water Management Academic Press, Netherlands

8. Mohd Saufi bin Rosmi. (2010). Synthesis of high quality of CNT via decomposition of acethylene on unsupported catalyst derived from industrial waste". Thesis Bachelor of Science, University Teknologi Malaysia.

9. Shawabkeh, R. A. (2010). Hydrometallurgical extraction of Zinc from Jordanian electric arc furnace dust. Hydrometallurgy, 104 (1): $61-65$.

10. Fallman, A.-M. (2000). Leaching of Chromium and Barium from steel slag in laboratory and field tests- a solubility controlled process? Waste Management, 20 (2-3): 149 -154.

11. Orhan, G. (2005). Leaching and cementation of heavy metals from electric arc furnace dust in alkaline medium. Hydrometallurgy, 78 (3-4): $236-245$.

12. Pode, V., Popovici, E., Pode, R. and Georgescu, V. (2007). Magnetic properties of an adsorbent based on modified natural zeolite. Revue Roumaine Chimie, 52 (10): 983 - 989.

13. Faria, P. C. C., Orfão, J. J. and Pereira, M. F. (2004). Adsorption of anionic and cationic dyes on activated carbons with different surface chemistry. Water Research, 38 (8): 2043 - 2052.

14. Tantriratna, P., Wirojanagud, W., Neramittagapong, S., Wantala, K. and Grisdanurak, N. (2011). Optimization for UV-Photocatalytic degradation of paraquat over titanium dioxide supported on rice husk silica using BoxBehnken Design. Indian Journal of Chemical Technology, 18: 363 - 371. 